\title{
RAPID POPULATION DIFFERENTIATION IN A MOSAIC ENVIRONMENT
}

\author{
III. MEASURES OF SELECTION PRESSURES
}

\author{
M. S. DAVIES and R. W. SNAYDON \\ Botany Department, University College, Cardiff and the Agricultural Botany Department, \\ University of Reading
}

Received 4.viii.75

\section{SUMMARY}

1. Reciprocal transplants were made of pairs of contrasting populations of Anthoxanthum odoratum collected from the Park Grass Experiment at Rothamsted.

2. In most cases, plants survived longer, produced more tillers and produced more dry matter when transplanted into their native plots than when transplanted into ecologically contrasting plots.

3. The average half-life of plants transplanted into contrasting plots was 8 months, that of plants in their native plots was about 2 years.

4. Selection coefficients against "alien" populations based on survival after 18 months ranged from 0.09 to 0.77 with a mean value of 0.36 . Similar coefficients of selection were calculated for tiller number and plant weight.

5. The coefficients of selection on the various plots were correlated with both the yield of herbage on the plots and the vegetation height on the plots, this is discussed in relation to the observed pattern of differentiation of $A$. odoratum on the plots.

6 . We conclude that selection pressures acting upon $A$. odoratum in the mosaic of environments that occur on the Park Grass Experiment are large and sufficient to account for the morphological and physiological differences that have been observed between closely adjacent populations of $A$. odoratum on the plots.

\section{INTRODUCTION}

Morphological and physiological differences have evolved between populations of Anthoxanthum odoratum L. on the Park Grass Experiment within a period of less than 60 years and over distances of less than a metre (Snaydon, 1970; Snaydon and Davies, 1972, 1976; Davies and Snaydon, 1973a, 1973b, 1974; Davies, 1975). The differences between populations are apparently adaptive and are seed transmitted. If the differences arose as a result of natural selection acting upon genetic variation within the original population, then selection must be intense and the potential store of genetic variation large.

We have no measure of the amount of genetic variability within the original population but the present populations are genetically very variable (Davies and Snaydon, in preparation). Other studies, such as those by Cooper (1959) have shown that large amounts of potential genetic variation are present even within individual plants of perennial outcrossing species and that this variation is susceptible to recombination and artificial selection. The large amount of genetic variation within populations of grass species in the field is also subject to natural selection, and large changes in the genetic structure of populations can occur within a few years (Charles, 1961, 1964; Brougham and Harris, 1967; Crossley and Bradshaw, 1968). 
In mosaic environments, such as the Park Grass Experiment, where the boundaries between environments are sharp and the area of each environment is relatively small, population differentiation will depend largely upon the relative magnitude of the opposing forces of selection and gene flow; Wright (1951), Mather (1955), Stebbins (1964), and Jain and Bradshaw (1966) have discussed the interaction of these forces. Intense artificial selection can outweigh the effects of high gene flow (Thoday and Boam, 1959; Streams and Pimental, 1961; Paterniani, 1969), though other workers (Robertson, 1970) have not been able to demonstrate population divergence under conditions of high gene flow. However, gene flow in the field may not be as large as has been previously assumed (Bateman, 1947; Griffiths, 1950; Copeland and Hardin, 1970; Gleaves, 1973), whilst recent estimates of selection coefficients (Jain and Bradshaw, 1966; Cook, Lefébvre and McNeilly, 1972) indicate that selection may be much more intense than envisaged by Haldane (1948) and Fisher (1950) in their early mathematical analysis of selection.

This study is an attempt to measure the magnitude of selection pressures operating within the species $A$. odoratum on some plots of the Park Grass Experiment in order to assess whether these were sufficient to account for the rapid changes in population structure that have occurred, both in time and space, in the area. A reciprocal transplant technique was used, plant survival and performance was followed over a period of 18 months. Unfortunately, because of the nature of the experimental area, no estimate of the reproductive performance of the transplants could be obtained.

\section{Materials AND method}

Approximately 25 plants, ranging in size from 2-6 tillers were collected at random from each of plots 3U, 1U, 7U, 9L, 1L and 8L in November 1967. Plants were grown in boxes filled with John Innes No. 1 potting compost until May 1968 when they were planted as spaced plants in a garden bed. Material was collected from these plants in November 1968 for reciprocal transplants. For the purposes of the transplant experiment, the populations were grouped into pairs from contrasting plots; thus population $9 \mathrm{~L}$ was paired with population $3 \mathrm{U}$ on the basis of the contrasting fertiliser treatments on their source plots (table 1 ), though the soil $p \mathrm{H}$ of the two plots was similar. Population $1 \mathrm{~L}$ was paired with population $\mathrm{IU}$ because of the widely different soil $p \mathrm{H}$ brought about by the contrasting liming treatment, though similar fertiliser treatment, on the two plots. Population 8L was paired with population $7 \mathrm{U}$, again on the basis of contrasting liming and fertiliser treatment but in this case the unlimed plot had a greater yield of herbage.

One hundred rametes, each of two tillers, were collected at random from each population accession, 50 of these rametes were transplanted into the native plot of the population and the other 50 were transplanted into the plot of the contrasting paired population. The rametes of the two populations were planted alternately, at $0.3 \mathrm{~m}$ intervals along two rows, which were located $0.5 \mathrm{~m}$ and $1 \mathrm{~m}$ respectively from the edge of the plot. Each plant was marked with coloured wire, so that it could be easily located. Plants which had failed to establish 3 weeks after the initial planting were replaced.

Plant survival and numbers of tillers per plant were measured in May 1969, October 1969 and May 1970. The vegetation on the plots is normally 
TABLE 1

The environmental conditions on the source plots of the three reciprocal pairs of populations of Anthoxanthum odoratum from the Park Grass Experiment, Rothamsted. (Park Grass data from Warren and Fohnson, 1964)

\begin{tabular}{|c|c|c|c|c|c|c|c|}
\hline $\begin{array}{l}\text { Population } \\
\text { pairs }\end{array}$ & $\begin{array}{c}\text { Fertiliser } \\
\text { treatment }\end{array}$ & $\begin{array}{l}\text { Mean annual } \\
\text { yield of } \\
\text { vegetation } \\
\left(\mathrm{kg}^{\left.-\mathrm{ha}^{-1}\right)}\right. \\
(1920-59)\end{array}$ & $\begin{array}{c}\text { Vegetation } \\
\text { height } 1969 \\
(\mathrm{~mm})\end{array}$ & $\begin{array}{l}\text { Soil* } \\
p \mathrm{H}\end{array}$ & $\begin{array}{c}\text { Soil } \dagger \\
\mathbf{P} \\
(\mathrm{mg} / 100 \mathrm{~g})\end{array}$ & $\begin{array}{c}\underset{\text { Soil }}{+} \\
\mathrm{K} \\
(\mathrm{mg} / 100 \mathrm{~g})\end{array}$ & $\begin{array}{c}\% \mathrm{~N} \text { in } \\
\text { surface } \\
\text { soil }\end{array}$ \\
\hline$\left\{\begin{array}{l}9 \mathrm{~L} \\
3 \mathrm{U}\end{array}\right.$ & $\begin{array}{c}\mathrm{N}_{2} \mathrm{P}, \mathrm{K}, \mathrm{Na}, \mathrm{Mg} \\
\text { unfertilised }\end{array}$ & $\begin{array}{l}5613 \\
1475\end{array}$ & $\begin{array}{l}580 \\
110\end{array}$ & $\begin{array}{l}5 \cdot 3 \\
5 \cdot 2\end{array}$ & $\begin{array}{r}10 \cdot 0 \\
0.5\end{array}$ & $\begin{array}{l}7 \cdot 7 \\
1 \cdot 1\end{array}$ & $\begin{array}{l}0 \cdot 31 \\
0 \cdot 27\end{array}$ \\
\hline$\left\{\begin{array}{l}1 \mathrm{~L} \\
1 \mathrm{U}\end{array}\right.$ & $\begin{array}{l}N_{1} \\
N_{1}\end{array}$ & $\begin{array}{l}2363 \\
1700\end{array}$ & $\begin{array}{l}160 \\
120\end{array}$ & $\begin{array}{l}7 \cdot 2 \\
4 \cdot 0\end{array}$ & $\begin{array}{l}1 \cdot 0 \\
0.5\end{array}$ & $\begin{array}{l}0.5 \\
1 \cdot 2\end{array}$ & $\begin{array}{l}0 \cdot 30 \\
0 \cdot 24\end{array}$ \\
\hline$\left\{\begin{array}{l}8 \mathrm{~L} \\
7 \mathrm{U}\end{array}\right.$ & $\begin{array}{c}\mathrm{P}, \mathrm{Na}, \mathrm{Mg} \\
\mathrm{P}, \mathrm{K}, \mathrm{Na}, \mathrm{Mg}\end{array}$ & $\begin{array}{l}2150 \\
3650\end{array}$ & $\begin{array}{l}230 \\
270\end{array}$ & $\begin{array}{l}7 \cdot 0 \\
4 \cdot 9\end{array}$ & $\begin{array}{l}11 \cdot 0 \\
13 \cdot 0\end{array}$ & $\begin{array}{r}0.5 \\
11 \cdot 3\end{array}$ & $\begin{array}{l}0 \cdot 31 \\
0 \cdot 23\end{array}$ \\
\hline
\end{tabular}

$\mathrm{U}=$ unlimed plots, $\mathrm{L}=$ limed plots $(2250 \mathrm{~kg} \mathrm{CaO} /$ ha every 4 years since 1903$)$

Annual applications: $\quad \mathrm{N}_{1}=48 \mathrm{~kg}, \mathrm{~N}, \mathrm{ha}^{-1} \quad \mathrm{~N}_{2}=96 \mathrm{~kg}, \mathrm{~N}, \mathrm{ha}^{-1}$

$$
\begin{aligned}
\mathrm{P} & =34 \mathrm{~kg}, \mathrm{P}, \mathrm{ha}^{-1} \\
\mathrm{Mg} & =11 \mathrm{~kg}, \mathrm{Mg}, \mathrm{ha}^{-1} \quad \mathrm{Na}=225 \mathrm{~kg}, \mathrm{~K}, \mathrm{ha}^{-1} \\
& * \text { Suspension } 1: 2 \cdot 5 \text { in water. } \\
& \\
& \neq \text { Extracted in } 0 \cdot 5 \mathrm{M} \text { sodium bicarbonate. }
\end{aligned}
$$

cut twice annually, in June and in autumn, and measurements were made a few weeks before these cuts. The plants were finally removed in May 1970 when dry weight yield per plant, plant height and tiller number were recorded.

\section{Results}

\section{(i) Plant survival}

The number of plants surviving, expressed as a percentage of the total planted for each population on each plot, decreased rapidly with time (fig. 1). After 18 months the average survival of populations transplanted into their native plots was 65 per cent and of populations transplanted into contrasting plots was 40 per cent. The largest difference in survival for any one population was for population $3 \mathrm{U}$; on its native plot 55 per cent of the plants survived but on plot 9L only 14 per cent survived after 18 months (table 2). At the same time, 60 per cent of the plants of the reciprocal population (9L) survived on its native plot and 50 per cent on the alien plot $3 \mathrm{U}$.

\section{(ii) Plant growth}

The surviving plants of populations transplanted into their native plots generally grew more rapidly than those transplanted into alien plots (table 2). For example, after 18 months' growth plants of populations transplanted into their native plots averaged 8.8 tillers per plant, but transplanted into alien plots, they averaged only 5.8 tillers (fig. 2 and table 2). Similarly the mean dry weight yield of surviving plants transplanted into their native plot was $470 \mathrm{mg}$, but that of transplants into alien plots was only $345 \mathrm{mg}$, a difference of 36 per cent (table 2). The largest difference for any population was found for population 9L which yielded $614 \mathrm{mg}$ on its native plot but only $364 \mathrm{mg}$ on plot $3 \mathrm{U}$, a difference of 69 per cent. Similar but less pronounced differences occurred in other populations. 


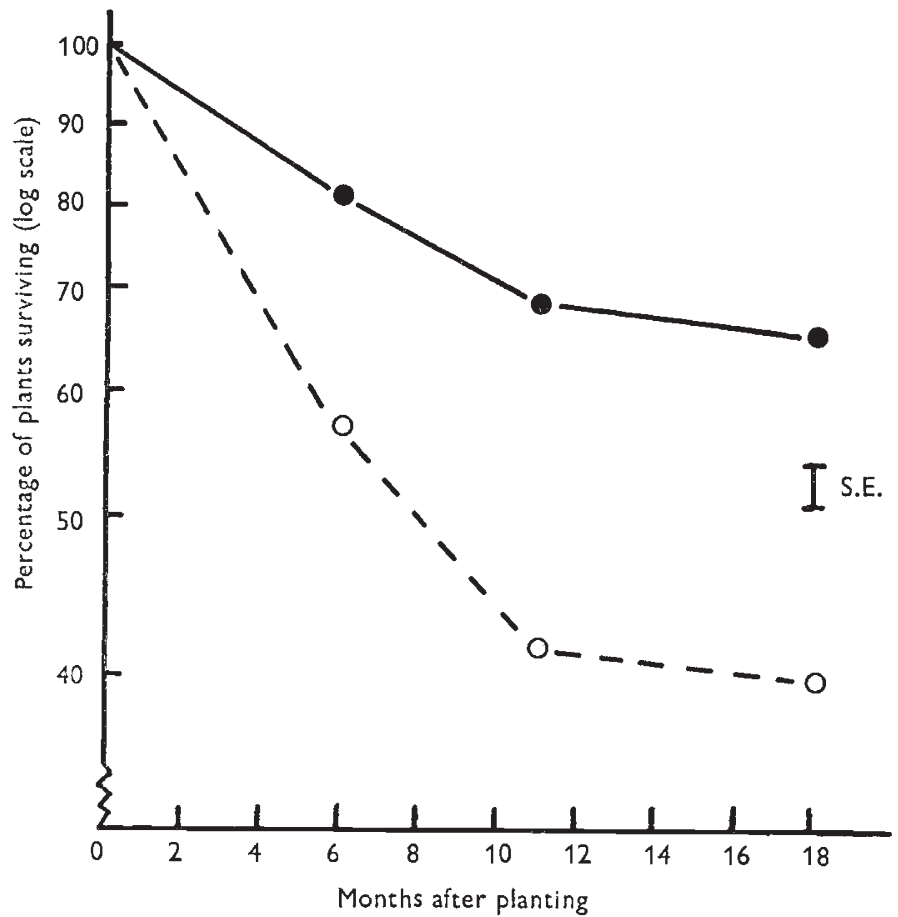

Fig. 1.-The mean survival (percentage) of plants transplanted into their native plots $(-)$ and into contrasting plots (-----), 6, 11 and 18 months after planting.

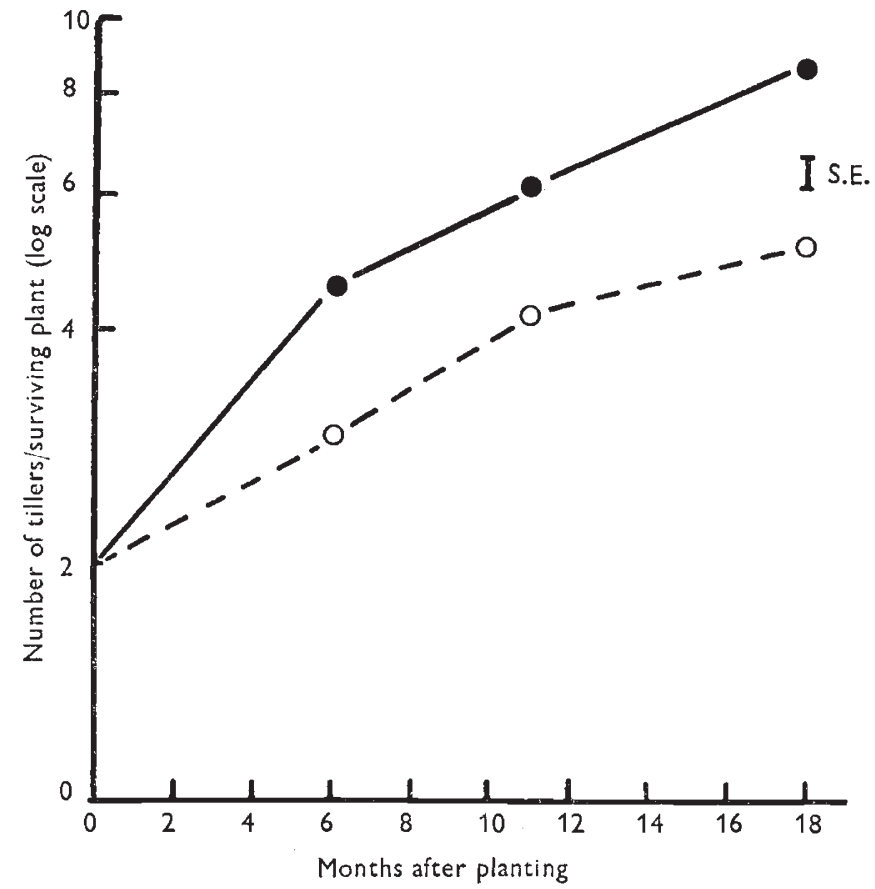

Fic. 2.- The mean tiller number per surviving plant of plants transplated into their native plots (-) and into contrasting plots (---) 611 and 18 months after planting. 
TABLe 2

The plant survival, mean number of tillers, mean plant height and mean plant weight of six populations of A. odoratum, 18 months after being transplanted into their native plots and into contrasting plots

\begin{tabular}{|c|c|c|c|c|c|c|c|c|}
\hline \multirow[b]{2}{*}{ Plot } & \multicolumn{2}{|c|}{ Survival \% } & \multicolumn{2}{|c|}{ Tiller number } & \multicolumn{2}{|c|}{ Plant height (mm) } & \multicolumn{2}{|c|}{ Plant weight (mg) } \\
\hline & Native & Contrasting & Native & Contrasting & Native & Contrasting & Native & Contrasting \\
\hline Population & 60 & 50 & $10 \cdot 4$ & $6 \cdot 4$ & 114 & 85 & 614 & 364 \\
\hline$\left\{\begin{array}{l}\mathrm{N} \\
3 \mathrm{U}\end{array}\right.$ & 55 & 14 & 8.5 & 4.5 & 87 & 100 & 451 & 491 \\
\hline$\left\{\begin{array}{l}1 \mathrm{~L} \\
1 \mathrm{U}\end{array}\right.$ & $\begin{array}{l}82 \\
61\end{array}$ & $\begin{array}{l}54 \\
49\end{array}$ & $\begin{array}{l}8 \cdot 3 \\
9 \cdot 4\end{array}$ & $\begin{array}{l}7 \cdot 1 \\
6 \cdot 4\end{array}$ & $\begin{array}{l}84 \\
80\end{array}$ & $\begin{array}{l}82 \\
78\end{array}$ & $\begin{array}{l}476 \\
491\end{array}$ & $\begin{array}{l}395 \\
310\end{array}$ \\
\hline$\left\{\begin{array}{l}8 \mathrm{~L} \\
7 \mathrm{U}\end{array}\right.$ & $\begin{array}{l}76 \\
69\end{array}$ & $\begin{array}{l}54 \\
38\end{array}$ & $\begin{array}{l}7 \cdot 8 \\
8 \cdot 4\end{array}$ & $\begin{array}{l}4 \cdot 9 \\
5 \cdot 4\end{array}$ & $\begin{array}{l}78 \\
94\end{array}$ & $\begin{array}{l}88 \\
84\end{array}$ & $\begin{array}{l}391 \\
395\end{array}$ & $\begin{array}{l}264 \\
248\end{array}$ \\
\hline $\begin{array}{l}\text { Mean } \\
\text { S.E. }\end{array}$ & $67 \cdot 1$ & $3 \cdot 4^{43 \cdot 2}$ & $8 \cdot 8$ & $0 \cdot 30^{5 \cdot 8}$ & $89 \cdot 5$ & $4 \cdot 8^{86 \cdot 2}$ & $496 \cdot 7$ & $28 \cdot 4^{345 \cdot 3}$ \\
\hline
\end{tabular}

(iii) Selection coefficients

Coefficients of selection against the " alien" population were calculated from the survival, tiller number and plant yield data on each plot at each measurement date (table 3 ). The coefficient of selection against the alien population was calculated as

$$
1 \cdot 0-\frac{\text { Performance of the alien population }}{\text { Performance of the native population }}
$$

The coefficients of selection against the alien population were invariably greatest on plot 9L and least on plot $3 \mathrm{U}$ (table 3 ). Coefficients of selection were also greater on limed plots (mean $=0.44$ ) than on unlimed plots $($ mean $=0.21)$.

The mean coefficient of selection on each plot was correlated with both the mean annual yield of the plots $(r=0.90, \mathrm{P}<0.05)$ and the height of the vegetation on the plots $(r=0.95, \mathrm{P}<0.01)$.

TABLE 3

Coefficients of selection against the "alien" population on six plots of the Park Grass Experiment

\begin{tabular}{|c|c|c|c|c|c|c|c|c|}
\hline \multirow[b]{2}{*}{ Plot } & \multicolumn{3}{|c|}{ Survival \% } & \multicolumn{3}{|c|}{ Tiller number } & \multirow{2}{*}{$\begin{array}{c}\text { Dry matter } \\
\text { yield } \\
\text { May } 1970\end{array}$} & \multirow[b]{2}{*}{ Mean } \\
\hline & $\begin{array}{l}\text { May } \\
1969\end{array}$ & $\begin{array}{l}\text { Oct. } \\
1969\end{array}$ & $\begin{array}{l}\text { May } \\
1970\end{array}$ & $\begin{array}{l}\text { May } \\
1969\end{array}$ & $\begin{array}{l}\text { Oct. } \\
1969\end{array}$ & $\begin{array}{l}\text { May } \\
1970\end{array}$ & & \\
\hline$\left\{\begin{array}{l}9 \mathrm{~L} \\
3 \mathrm{U}\end{array}\right.$ & $\begin{array}{l}0.67 \\
0.08\end{array}$ & $\begin{array}{l}0 \cdot 74 \\
0 \cdot 07\end{array}$ & $\begin{array}{l}0 \cdot 77 \\
0 \cdot 09\end{array}$ & $\begin{array}{l}0.58 \\
0.17\end{array}$ & $\begin{array}{l}0.55 \\
0.17\end{array}$ & $\begin{array}{l}0 \cdot 57 \\
0 \cdot 25\end{array}$ & $\begin{array}{l}0 \cdot 60 \\
0 \cdot 20\end{array}$ & $\begin{array}{l}0 \cdot 64 \\
0 \cdot 15\end{array}$ \\
\hline$\left\{\begin{array}{l}1 \mathrm{~L} \\
1 \mathrm{U}\end{array}\right.$ & $\begin{array}{l}0 \cdot 29 \\
0 \cdot 12\end{array}$ & $\begin{array}{l}0 \cdot 42 \\
0 \cdot 10\end{array}$ & $\begin{array}{l}0 \cdot 40 \\
0 \cdot 12\end{array}$ & $\begin{array}{l}0.42 \\
0.29\end{array}$ & $\begin{array}{l}0.23 \\
0.26\end{array}$ & $\begin{array}{l}0 \cdot 23 \\
0 \cdot 25\end{array}$ & $\begin{array}{l}0 \cdot 35 \\
0 \cdot 20\end{array}$ & $\begin{array}{l}0 \cdot 33 \\
0 \cdot 19\end{array}$ \\
\hline$\left\{\begin{array}{l}8 \mathrm{~L} \\
7 \mathrm{U}\end{array}\right.$ & $\begin{array}{l}0 \cdot 31 \\
0 \cdot 15\end{array}$ & $\begin{array}{l}0 \cdot 50 \\
0 \cdot 22\end{array}$ & $\begin{array}{l}0.54 \\
0.22\end{array}$ & $\begin{array}{l}0.24 \\
0.29\end{array}$ & $\begin{array}{l}0 \cdot 20 \\
0 \cdot 33\end{array}$ & $\begin{array}{l}0 \cdot 31 \\
0 \cdot 42\end{array}$ & $\begin{array}{l}0.39 \\
0.36 \\
\text { S.E. }\end{array}$ & $\begin{array}{r}0 \cdot 36 \\
0 \cdot 28 \\
=0 \cdot 05\end{array}$ \\
\hline $\begin{array}{l}\text { Mean of } \\
\text { limed plots }\end{array}$ & 0.42 & 0.55 & 0.57 & $0 \cdot 41$ & 0.33 & $0 \cdot 37$ & ${ }^{0.41}$ S.E. & $\begin{array}{l}0.44 \\
0.03\end{array}$ \\
\hline $\begin{array}{l}\text { Mean of } \\
\text { unlimed plots }\end{array}$ & $0 \cdot 12$ & $0 \cdot 13$ & $0 \cdot 14$ & $0 \cdot 25$ & $0 \cdot 25$ & $0 \cdot 31$ & $\begin{array}{c}0 \cdot 25 \\
\text { an of all plot }\end{array}$ & $\begin{array}{l}0 \cdot 21 \\
0 \cdot 33\end{array}$ \\
\hline
\end{tabular}




\section{Discussion}

Each population generally performed best in its native plot, though the superiority was not consistent across all measured attributes. Indeed there was some evidence that if a population performed better in one attribute it might be compensated by a relatively poorer performance in another. For example, in the reciprocal pair of populations $9 \mathrm{~L}$ and $3 \mathrm{U}$, there was little difference in survival of plants of population $9 \mathrm{~L}$ on native and alien plots (table 2) but a large difference in dry weight yield; conversely there was a large difference in the survival of population $3 \mathrm{U}$ but no significant difference in yield (table 2).

Observation was not continued for long enough to adequately determine the half-life of populations on both native and alien plots. On alien plots, populations had an average half-life of 8 months (fig. 1). Extrapolation of the data for native plots (fig. 1) indicates a probable average half-life of 2 years; this is similar to the value obtained by Antonovics (1972) for $A$. odoratum growing on zinc contaminated mine waste.

The coefficients of selection against alien populations measured here are relatively large, with a mean value of $0 \cdot 33$. These values are not as large as those obtained in more extreme habitats, such as heavy metal contaminated spoil heaps, where selection coefficients of 0.9 and more seem normal (Jain and Bradshaw, 1966).

The largest coefficients of selection occurred on plots characterised by large annual yield and tall vegetation in summer. These plots have received heavy applications of fertiliser and lime (table 1). The lowest selection coefficients occurred on plots with small annual yield and short vegetation. The correlation between selection coefficient and vegetation height $(r=0.95)$ may reflect the role of competition for light as a selective force. Populations of Anthoxanthum odoratum collected from plots with tall vegetation are taller (Snaydon and Davies, 1972) and more tolerant of low light conditions (Davies, 1970) than populations from plots with short vegetation.

The greater selection coefficients against alien populations on limed plots (table 3) may be partly associated with the generally greater height and yield of the vegetation (table 1), but populations of $A$. odoratum collected from limed and unlimed plots of the Park Grass Experiment also differ in response to acid and calcareous soils (Snaydon, 1970) and in response to a number of specific soil nutrient factors (Davies and Snaydon, 1973a, 1973b, 1974).

The selection coefficients against alien populations on limed plots were greater when calculated on the survival data than when calculated on the growth performance of surviving plants, tiller number and dry weight yield; on unlimed plots the reverse was true. This indicates that the mechanism of selection may be different on the various plots.

The technique used here to estimate the magnitude of selection operating in situ on the Park Grass Experiment is subject to several major criticisms. Firstly, the estimate of the selection coefficient on each plot is directly dependent upon the particular alien population transplanted into that plot, the greater the contrast between the native and alien population, the greater the estimated selection coefficient on that plot. Ideally, all populations should be transplanted into all plots, though this would have tripled the size of the present experiment. Secondly, selection acting upon germinating and 
establishing seedlings was not considered here. Coefficients of selection were estimated on the basis of survival and vegetative growth of rooted tillers and plants which failed to establish were replaced 3 weeks after planting. Selection during seedling establishment is probably important and intense. For example, Charles (1961) found large differences between cultivars of grasses in survival during the first year when sown in dense mixtures. Thirdly, no measures were made of possible differences in viable seed set between populations on the various plots. The reproductive capacity of genotypes is probably important in determining the genetic structure of populations, especially in a relatively short lived species such as $A$. odoratum. It is possible, therefore, that selection pressures acting upon the species on the Park Grass Experiment may be even greater than estimated here.

The selection pressures estimated above are large and probably sufficient to account for the differences already observed between populations of A. odoratum on the Park Grass Experiment (Snaydon, 1970; Snaydon and Davies, 1972; Davies and Snaydon, 1973a, 1973b, 1974). The selection pressures are also large enough to account for the sharp differences that occur between populations at plot boundaries (Snaydon and Davies, unpublished) if gene flow is as slight as Griffiths (1950), Copeland and Hardin (1970) and Snaydon and Davies (unpublished) indicate.

Acknowledgments.-We are grateful to the late Sir Frederick Bawden for permission to use the Park Grass Experiment, and to Mr G. V. Dyke, Miss J. M. Thurston and Mr D. Williams for their help and encouragement. We acknowledge the financial support of the Science Research Council.

\section{REFERENCES}

Antonovics, J. 1972. Population dynamics of the grass Anthoxanthum odoratum on a zinc mine. F. Ecol., 60, 351-365.

BATEMAN, A. J. 1947. Contamination in seed crops. III. Relation with isolation distance. Heredity, 1, 303-336.

BROUGHAM, R. w., AND HARRIS, w. 1967. Rapidity and extent of changes in genotype structure induced by grazing in a ryegrass population. New Zealand F. Agric. Res., 10, 56-65.

Charles, A. H. 1961. Differential survival of cultivars of Lolium, Dactylis and Phleum. 7. Br. Grassld. Soc., 16, 69-75.

charles, A. H. 1964. Differential survival of plant types in swards. 7. Br. Grassld. Soc., 19, 198-204.

COOK, S. A., LefÉbVRE, G., AND MGNeILly, T. 1972. Competition between metal tolerant and normal plant populations in normal soil. Evolution, 26, 366-372.

COOPER, J. P. 1959. Selection and population structure in Lolium. III. Selection for date of ear emergence. Heredity, 13, 461-480.

COPELAND, L. O., AND HARDIN, E. E. 1970. Outcrossing in ryegrass (Lolium spp.) as determined by fluorescence tests. Crop. Sci., 10, 254-257.

GRosSLEY, G. K., AND BRADShAW, A. D. 1968. Differences in response to mineral nutrients of populations of ryegrass, Lolium perenne L. and orchardgrass Dactylis glomerata L. Crop Sci., 8, 383-387.

DAvies, M. S. 1970. The Ecological Genetics of Anthoxanthum odoratum L. on the Park Grass Experiment, Rothamsted. Ph.D. thesis, University of Reading.

DAvies, M. s. 1975. Physiological differences among populations of Anthoxanthum odoratum L. collected from the Park Grass Experiment, Rothamsted. IV. Response to potassium and magnesium. 7. appl. Ecol., 12, 953-964.

DAvies, M. s., AND SNAYDON, R. w. 1973a. Physiological differences among populations of Anthoxanthum ororatum L. collected from the Park Grass Experiment, Rothamsted. I. Response to calcium. 7. appl. Ecol., 10, 33-45.

$36 / 1-\mathrm{E}$ 
Davies, M. s., ANd Snaydon, R. w. 1973b. Physiological differences among populations of Anthoxanthum odoratum L. collected from the Park Grass Experiment, Rothamsted. II. Response to aluminium. 3. appl. Ecol., 10, 47-55.

DAVIES, M. S., AND SNAYDON, R. W. 1974. Physiological differences among populations of Anthoxanthum ororatum L. collected from the Park Grass Experiment, Rothamsted. III. Response to phosphate. 7. appl. Ecol. 11, 699-708.

FISHER, R. A. 1950. Gene frequencies in a cline as determined by selection and diffusion. Biometrics, 6, 353-361.

gleaves, J. T. 1973. Gene flow mediated by wind borne pollen. Heredity, 31, 355-366.

GRIFFITHS, D. J. 1950. The liability of seed crops of perennial ryegrass (Lolium perenne) to contamination by wind borne pollen. 7. Agric. Sci., 40, 19-38.

haldane, J. B. s. 1948. The theory of a cline. J. Genet., 48, 277-284.

JAIN, S. K., AND BRADSHAW, A. D. 1966. Evolutionary divergence among adjacent plant populations. I. The evidence and its theoretical analysis. Heredity, 21, 407-441.

MATher, K. 1955. Polymorphism as an outcome of disruptive selection. Evolution, 9, $52-61$.

PATERNIANI, E. 1969. Selection for reproductive isolation between two populations of maize, Zea mays L. Evolution, 23, 534-547.

ROBERTSON, A. 1970. A note on disruptive selection experiments in Drosophila. Am. Nat., 104, 561-569.

SNAYDON, R. W. 1970. Rapid population differentiation in a mosaic environment. I. The response of Anthoxanthum odoratum populations to soils. Evolution, 24, 257-269.

SNAYDON, R. W., AND DAviEs, M. s. 1972. Rapid population differentiation in a mosaic environment. II. Morphological variation in Anthoxanthum odoratum. Evolution, 26, 390-405.

Stebbins, G. L. (1964). The Evolution of animal species. Review of book by E. Mayr. Evolution, 18, 134-137.

STREAMS, F. A., AND PIMENTAL, D. 1961. Effects of immigration on the evolution of populations. Am. Nat., 95, 201-210.

THODAY, J. м., AND вOAM, т. в. 1959. Effects of disruptive selection. II. Polymorphism and divergence without isolation. Heredity, 13, 205-218.

warren, R. G., And Johnston, A. E. 1964. The Park Grass Experiment. Rep. Rothamsted. Exptl. Sta., 1963, 240-262.

WRIGHT, s. 1951. The genetical structure of populations. Ann. Eugenics, 15, 323-354. 